Eixo Temático: 0 trabalho pedagógico e a didática desde a perspectiva da subjetividade

\title{
A Plenarinha da Educação Infantil nas Escolas Públicas do Distrito Federal como campo de configuração e expressão subjetiva das crianças
}

Ivete Mangueira de Souza Oliveira Secretaria de Estado de Educação do Distrito Federal

ivemangueira@gmail.com

Cristina Massot Madeira-Coelho

Universidade de Brasília cristina.madeira.coelho@gmail.com

\section{Resumo}

A Plenarinha é um projeto desenvolvido pela Secretaria de Estado de Educação do Distrito Federal, em todas as escolas públicas e conveniadas do Distrito Federal que ofertam Educação Infantil, chegando em 2019, no seu sétimo ano. Tem como principal objetivo possibilitar às crianças da Educação Infantil no exercício das experiências e vivências na escola um trabalho que busca promover a formação com e para a cidadania. A consonância com os eixos integrados do Currículo em Movimento da Educação Básica - Educação Infantil, ratifica a criança como centro da organização do trabalho pedagógico. A pesquisa pretende investigar e compreender se e como a Plenarinha pode favorecer a expressão subjetiva das crianças da Educação Infantil no cotidiano da escola e seus múltiplos espaços relacionais, vislumbrando ampliar o olhar para além da sala de aula. Um reconhecer que entendemos propor os espaços da escola, para além dos conteúdos, um espaço como lócus de produções sociais que criam e se reinventam nos processos relacionais em que o direito de participação e proteção das crianças dialogam e se articulam politicamente trazendo para o centro o protagonismo e o olhar das crianças sobre suas vivências, práticas pedagógicas, aprendizagens, tendo esses espaços como instâncias de formação para a cidadania. Tem como base a Teoria da Subjetividade, de Gonzalez Rey (2003) na perspectiva cultural-histórica que aponta para o sujeito como produtor criativo de sua própria existência a partir de suas próprias experiências. Será realizada numa escola pública do Distrito Federal, numa de suas regiões administrativas, em uma turma de Educação Infantil. O processo investigativo será ancorado pela Epistemologia Qualitativa, de Gonzalez Rey (2017), que pressupõe o processo de produção do conhecimento a partir de um caráter construtivo- 
interpretativo, singular e dialógico, nos permitindo pensar o presente e refletir sobre as aprendizagens nesses espaços relacionais da escola, percebidos aqui como territórios que provocam tensões e reações onde a criança pode criar, reelaborar e ressignificar produzindo sentidos subjetivos, configurações subjetivas e possibilidades de emergência do desenvolvimento subjetivo sobre o que experiencia e produz transformando a realidade e a si mesma, numa perspectiva cidadã. Os instrumentos serão: pesquisa documental, bibliográfica, observação, dinâmica conversacional, complementação de frases, filmagem, gravação áudios, podendo se ampliarem e terem a participação das crianças na construção de outros instrumentos.

Pergunta: Na perspectiva da Teoria da Subjetividade como podemos avançar na compreensão da aprendizagem para além dos objetivos da estrutura capitalista que orienta a escola e o educando é visto como "produto" do processo?

Palavras chave: Plenarinha. Cidadania. Teoria da Subjetividade.

\section{Referências}

GONZÁLEZ REY, Fernando Luis. Sujeito e subjetividade. Tradução Raquel Souza Lobo Guzzo. São Paulo: Pioneira Thomson Learning, 2003.

./ MITJANZ MAARTINEZ; A. Subjetividade: Teoria, Epistemologia e Método. Campinas, SP: Editora Alínea, 2017. 